\title{
Efficacy and tolerability of rimonabant in overweight or obese patients with type 2 diabetes: a randomised controlled study
}

\author{
André J Scheen ${ }^{1}$, Nick Finer ${ }^{2}$, Priscilla Hollander ${ }^{3}$, Michael D Jensen ${ }^{4}$, Lvc F Van Gaal ${ }^{5}$, for the RIO-Diabetes \\ Study Group ${ }^{*}$
}

${ }^{1}$ Division of Diabetes, Nutrition and Metabolic Disorders, CHU Sart Tilman, University of Liege, Liege, Belgium : ${ }^{2}$ Department of Medicine, School of Clinical Medicine, University of Cambridge, Cambridge, UK ; ${ }^{3}$ Ruth Collins Diabetes Center, Baylor University Medical Center, Dallas, TX, USA ; ${ }^{4}$ Endocrine Research Unit, Mayo Clinic, Rochester, MN, USA and ${ }^{5}$ Department of Diabetology, Metabolism and Clinical Nutrition, Antwerp University Hospital, Antwerp, Belgium

\section{Summary}

Background Rimonabant, a selective cannabinoid type 1 receptor blocker, reduces bodyweight and improves cardiovascular and metabolic risk factors in non-diabetic overweight or obese patients. The aim of the RIODiabetes trial was to assess the efficacy and safety of rimonabant in overweight or obese patients with type 2 diabetes that was inadequately controlled by metformin or sulphonylureas.

Methods 1047 overweight or obese type 2 diabetes patients (body-mass index $27-40 \mathrm{~kg} / \mathrm{m}^{2}$ ) with a haemoglobin $\mathrm{A}_{1 \mathrm{c}}\left(\mathrm{HbA}_{1 \mathrm{c}}\right)$ concentration of $6 \cdot 5-10 \bullet 0 \%$ (mean $7 \cdot 3 \%$ [SD $0 \bullet 9$ ] at baseline) already on metformin or sulphonylurea monotherapy were given a mild hypocaloric diet and advice for increased physical activity, and randomly assigned placebo ( $\mathrm{n}=348), 5 \mathrm{mg} /$ day rimonabant (360) or $20 \mathrm{mg} /$ day rimonabant (339) for 1 year. Two individuals in the $5 \mathrm{mg}$ /day group did not receive double-blind treatment and were thus not included in the final analysis. The primary endpoint was weight change from baseline after 1 year of treatment. Analyses were done on an intention-to-treat basis. This trial is registered at ClinicalTrials.gov, number NCT00029848.

Findings 692 patients completed the 1 year follow-up; numbers in each group after 1 year were much the same. Weight loss was significantly greater after 1 year in both rimonabant groups than in the placebo group (placebo: $-1 \cdot 4 \mathrm{~kg}$ [SD 3•6]; $5 \mathrm{mg} /$ day: $-2 \cdot 3 \mathrm{~kg}$ [4•2], $\rho=0 \bullet 01 \mathrm{vs}$ placebo; $20 \mathrm{mg} /$ day: $-5 \bullet 3 \mathrm{~kg}$ [5•2], $\rho<0 \bullet 0001 \mathrm{vs}$ placebo). Rimonabant was generally well tolerated. The incidence of adverse events that led to discontinuation was slightly greater in the $20 \mathrm{mg}$ /day rimonabant group, mainly due to depressed mood disorders, nausea, and dizziness.

Interpretation These data indicate that $20 \mathrm{mg}$ /day rimonabant, in combination with diet and exercise, can produce a clinically meaningful reduction in bodyweight and improve $\mathrm{HbA}_{1 \mathrm{c}}$ and a number of cardiovascular and metabolic risk factors in overweight or obese patients with type 2 diabetes inadequately controlled by metformin or sulphonylureas.

\section{Introduction}

Type 2 diabetes frequently co-exists with a cluster of other cardiovascular and metabolic risk factors including abdominal obesity, low HDL-cholesterol concentrations, high triglyceride concentrations, and raised blood pressure, ${ }^{1}$ and is considered to be a cardiovascular disease risk equivalent. ${ }^{2,3}$ A recent population-based retrospective cohort study showed that diabetes confers an equivalent cardiovascular risk to ageing 15 years in people aged 40 years or older. ${ }^{4}$ The treatment of multiple cardiovascular and metabolic risk factors is central to the management of type 2 diabetes. ${ }^{5}$

Being overweight or obese - in particular, abdominally obese - increases the risk of type 2 diabetes and cardiovascular disease, ${ }^{6,7}$ yet those with diabetes often have more difficulty in losing weight ${ }^{8}$ and experience weight gain associated with most antidiabetic medications. ${ }^{5}$

The endocannabinoid system, consisting of the cannabinoid type $1\left(\mathrm{CB}_{1}\right)$ receptor and endogenous lipid-derived ligands, ${ }^{9}$ seems to modulate energy homoeostasis as well as glucose and lipid metabolism, ${ }^{10-12}$ both through central orexigenic effects and peripheral metabolic effects in adipose tissue, liver, and skeletal muscle. ${ }^{13-15}$ Patients with obesity or hyperglycaemia caused by type 2 diabetes exhibit higher concentrations of endocannabinoids in visceral fat or serum, respectively, than the corresponding controls. ${ }^{16}$

In non-diabetic overweight or obese patients, $20 \mathrm{mg}$ daily of the selective $\mathrm{CB}_{1}$ receptor blocker rimonabant has been shown to produce substantial weight loss and waist circumference reduction (a key marker of intra-

\footnotetext{
* Group members listed at end of report
} 
abdominal adiposity), and improvements in multiple cardiovascular and metabolic risk factors. ${ }^{17,18}$ These data were further confirmed in overweight or obese patients with untreated dyslipidaemia. ${ }^{19}$ Part of these metabolic improvements could be attributed to a moderate, but significant, increase in plasma adiponectin levels. ${ }^{19}$

This multicentre randomised controlled trial was designed to assess the efficacy and safety of rimonabant in combination with a mild hypocaloric diet and advice for increased physical activity in overweight or obese patients with type 2 diabetes who were already on metformin or sulphonylurea monotherapy.

\section{Methods}

\section{Patients}

This randomised, double-blind, placebo-controlled study was done in 159 centres in 11 countries (in Europe, North America, and South America) between October, 2001, and May, 2004. Patients aged 18-70 years with type 2 diabetes who had been treated with metformin or sulphonylurea monotherapy for at least 6 months (stable dose for at least 3 months), but who remained inadequately controlled, were recruited. Inclusion criteria were body-mass index of 27-40 kg/m², a haemoglobin $A_{1 c}\left(\mathrm{HbA}_{1 \mathrm{c}}\right)$ level of $6 \cdot 5-10 \bullet 0 \%$, and a fasting glucose concentration of 5•55-15•04 mmol/L. Exclusion criteria were unstable bodyweight (defined as more than $5 \mathrm{~kg}$ variation within the past 3 months), any clinically significant disorder (including severe microvascular or macrovascular complications of diabetes), systolic blood pressure greater than $160 \mathrm{~mm} \mathrm{Hg}$ or diastolic blood pressure greater than $95 \mathrm{~mm} \mathrm{Hg}$, pregnancy or lactation, recent or planned changes in smoking status, use of anti-obesity drugs within the past 3 months, or use of any medication known to affect bodyweight (eg, antidepressants). Written informed consent was obtained from all patients.

The protocol was approved by the Institutional Review Board/Ethics Committee for each centre. The study was done in full compliance with the Declaration of Helsinki, with an independent, unblinded data safety monitoring board. ${ }^{17-19}$

\section{Procedures}

The protocol has been described previously ${ }^{17-19}$ A 2-week screening period preceded a 4-week, placebo run-in period, followed by randomisation to double-blind treatment. A randomisation code list, with a block size of three, was generated centrally by the sponsor. Treatments were allocated to patients with an interactive voice response system in accordance with the predefined randomisation list (1/1/1 ratio for placebo, $5 \mathrm{mg} / \mathrm{day}$ rimonabant, or $20 \mathrm{mg}$ /day rimonabant, respectively). The interactive voice response system ensured that the randomisation of treatment was balanced within all centres and was stratified on the basis of bodyweight loss $(\leq 2$ $\mathrm{kg}$ or $>2 \mathrm{~kg}$ ) during the run-in period and class of antidiabetic medication. All patients were put on a mild hypocalorific diet and were advised on increased physical activity during the run-in period and until the end of the study.

Standardised assessments of bodyweight, waist circumference, and vital signs were done at screening, twice during the run-in period, at baseline (randomisation), and post-randomisation at week 2, week 4, and monthly thereafter for 1 year. Glycaemic and lipid variables were measured at screening, baseline, week 12, 24, and 36, and at 1 year. Insulin resistance was calculated by use of the homoeostasis model assessment (HOMA-IR). ${ }^{20}$ The diagnosis of metabolic syndrome was assessed in accordance with National Cholesterol Education ProgramAdult Treatment Panel III (NCEP-ATP III) criteria. ${ }^{2}$

The primary endpoint was weight change from baseline at the last observation carried forward (LOCF). Secondary endpoints included changes in $\mathrm{HbA}_{1 \mathrm{c}}$, HDL cholesterol, triglyceride, fasting glucose, fasting insulin, high-sensitivity C-reactive protein (hsCRP), and leptin concentrations, prevalence of metabolic syndrome, ${ }^{2}$ waist circumference, and blood pressure. Measurements of $\mathrm{HbA}_{1 \mathrm{c}}$, glucose, insulin, total cholesterol, LDL and HDL cholesterol, triglyceride, leptin, and hsCRP were done at central laboratories (ICON Laboratories, Farmingdale, NY, USA and Dublin, Ireland), together with laboratory safety measurements in accordance with standard procedures. ${ }^{17-19} \mathrm{HbA}_{1 \mathrm{c}}$ was measured by ion exchange high-pressure liquid chromatography (Bio-Rad variant, Bio-Rad Laboratories, Hercules, CA, USA) with Diabetes Control and Complications Trial reference values.

The SF36 health survey questionnaire ${ }^{21}$ and a patient's satisfaction scale were included in the study as exploratory secondary parameters. Patients completed the obesity-specific Impact of Weight on Quality of Life (IWQoL-Lite) exploratory secondary questionnaire at baseline and every 3 months for 1 year. ${ }^{22,23}$ Food behaviour was also assessed by a Visual Analog Scale. ${ }^{24}$ 
Safety assessment was done regularly by an independent data safety and monitoring board and included standard adverse event reporting, vital signs, pulse-rate-corrected QT interval, and the Hospital Anxiety and Depression (HAD) scale. ${ }^{25}$

\section{Statistical analysis}

The sample size was calculated on the basis of the assumption that the SD of weight change at year 1 would be $10 \mathrm{~kg}$. Thus 990 randomised patients (330 patients in every group) would provide $95 \%$ confidence to detect a 3 $\mathrm{kg}$ difference between both doses of rimonabant and placebo after 1 year. An $\alpha$ level of 0.025 was chosen to ensure an overall type error rate of 0.05 according to a modified Bonferroni procedure.

Analyses were done on a modified intention-to-treat basis. The modified intention-to-treat population consisted of all randomised patients who were exposed to at least one dose of study drug and had at least one post-baseline assessment and, when appropriate, a baseline assessment.

The primary endpoint was analysed with analysis of variance with the modified Bonferroni procedure (Hochberg) to adjust for multiple doses. ${ }^{26}$ The three-way analysis of variance (ANOVA) model included terms for treatment and two randomisation strata (weight loss of $\leq 2 \mathrm{~kg}$ or $>2 \mathrm{~kg}$ during the run-in period and antidiabetic therapy with metformin or sulphonylurea); both doses of rimonabant were compared with placebo. As an assessment of sensitivity, a post-hoc repeated measures approach was done for changes in weight from baseline, because this analysis includes all measurements gathered over time during the study, and thus might provide a better assessment in the presence of missing data. ${ }^{27}$

The repeated measures model included a number of fixed effects (randomisation strata, treatment, number of days from randomisation, and treatment-by-day interaction) and a random effect (the patient). Additionally, as another assessment of sensitivity, a more conservative method than LOCF for handling missing data was used. For dropouts with post-baseline efficacy, the last value was set to the baseline value - ie, baseline observation carried forward (BOCF) - and the change from baseline was set to zero. ${ }^{28}$ Similar models, excluding randomisation strata, were applied to the secondary efficacy parameters.

Patients were classified as having a response of a $5 \%$ or $10 \%$ weight loss if they had a reduction in bodyweight from baseline at the LOCF of at least $5 \%$ or $10 \%$. The incidences of patients who had a weight loss of $5 \%$ and $10 \%$ and of those with metabolic syndrome at LOCF were analysed with logistic regression models. The models for patients who had weight losses of 5\% and 10\% included terms for treatment and randomisation strata, and the model for the metabolic syndrome included terms for treatment and the status of the metabolic syndrome at baseline.

The effect of rimonabant independent of weight loss was tested with analysis of covariance (ANCOVA) with weight loss (change in weight from baseline to 1 year) as a covariate. ${ }^{28}$ The statistical model for the weightadjusted treatment effect is as follows: $\mathrm{Y}=\mathrm{a}+\beta \mathrm{T}+\gamma \mathrm{W}+\mathrm{e}$ (ANCOVA model, weight adjusted) where $\mathrm{Y}$ is the efficacy variable, $\mathrm{T}$ is the treatment indicator, and $\mathrm{W}$ is weight loss. The weight-independent portion of the total treatment effect was calculated as the ratio of the weight-adjusted treatment effect, $\beta$, to the treatment effect in the overall unadjusted ANOVA model, $\beta_{1}$; determined from the ANOVA model: $Y=a+\beta_{1} \mathrm{~T}+\mathrm{e}_{1}{ }^{29}$ This ratio indicates the proportion of the total effect size that cannot be explained by weight loss.

All statistical tests were two-sided; all p values presented are unadjusted. Analyses were done with SAS software, version 8.2 .

This trial is registered at ClinicalTrials.gov, number NCT00029848.

\section{Role of the funding source}

The sponsor participated in discussions regarding study design and protocol development and provided logistical support during the trial. Data were gathered by the sponsor and were assessed jointly by the authors and the sponsor. Data were interpreted and the manuscript written by the authors, with editorial support provided by the sponsor. The corresponding author had full access to all the data and takes responsibility for the integrity of that data and the accuracy of the data analysis. The corresponding author had final responsibility for the decision to submit for publication. 
Figure 1: Trial profile

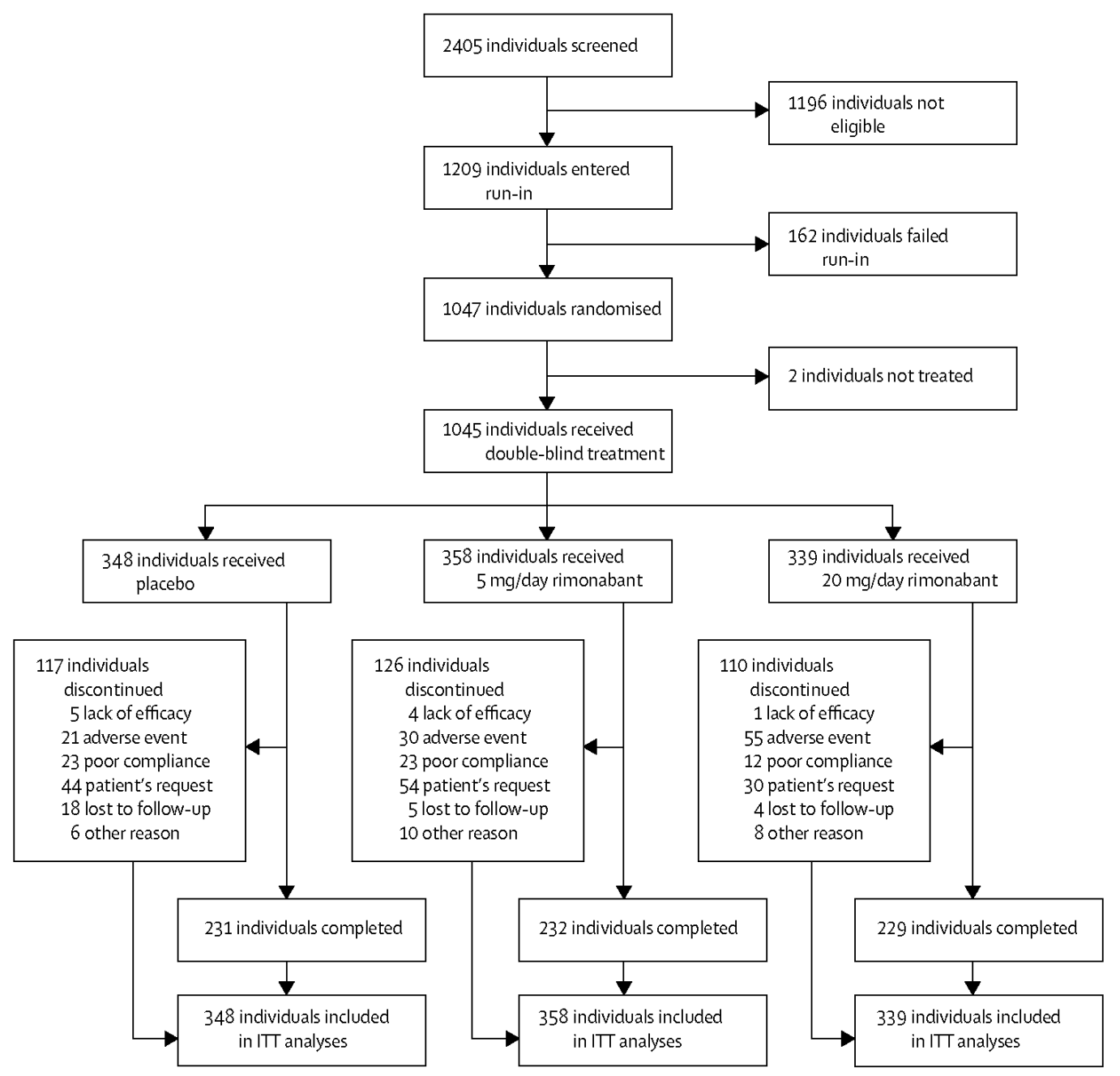

ITT=intention-to-treat.

\section{Results}

513 men and 532 women were randomised to double-blind treatment. 692 patients $(66 \cdot 2 \%)$ completed the 1-year follow-up (figure 1). Two randomised patients were not exposed to treatment and 11 randomised patients were excluded from the analysis of weight (two for non-exposure and nine for missing post-baseline weight assessment). Baseline characteristics were much the same in the three groups (table 1), except smoking, which was slightly lower in the $20 \mathrm{mg}$ /day rimonabant group $(\mathrm{p}=0.02)$, and fasting triglyceride concentrations, which were slightly higher in the $20 \mathrm{mg} /$ day rimonabant group ( $\mathrm{p}=0 \cdot 03$ ) At screening, mean weight was $96 \cdot 3 \mathrm{~kg}$ (SD 14.7), mean waist circumference $109 \mathrm{~cm}(10 \cdot 8)$, mean $\mathrm{HbA}_{1 \mathrm{c}} 7 \cdot 3 \%(0 \cdot 9)$, mean fasting plasma glucose concentration of $8.3 \mathrm{mmol} / \mathrm{L}(2 \cdot 1)$, and mean prevalence of metabolic syndrome was $79 \%$. Mean reductions in weight $(-1 \cdot 5 \mathrm{~kg}[1 \cdot 8])$, waist circumference $\left(-1 \cdot 4 \mathrm{~cm} \mathrm{[3 \cdot 3]),} \mathrm{HbA}_{\mathrm{lc}}(-0 \cdot 24 \%\right.$ [0.54]), fasting plasma glucose concentration $(-0.52 \mathrm{mmol} / \mathrm{L}[1 \cdot 87])$, fasting plasma insulin concentration $(-1 \cdot 1 \mu \mathrm{lU} / \mathrm{mL}[10 \cdot 5])$, triglyceride concentration $(-1 \cdot 3 \%[35 \cdot 3])$, HDL-cholesterolconcentration $(-1 \cdot 9 \%[11 \cdot 5])$, and systolic blood pressure $(-2 \cdot 1$ $\mathrm{mm} \mathrm{Hg} \mathrm{[11.7])} \mathrm{were} \mathrm{seen} \mathrm{after} \mathrm{the} \mathrm{placebo} \mathrm{run-in.} \mathrm{99.4 \%} \mathrm{(338} \mathrm{of} \mathrm{340),} \mathrm{98.9 \%} \mathrm{(349} \mathrm{of} \mathrm{353),} \mathrm{and} \mathrm{99.1 \%} \mathrm{(336} \mathrm{of}$ 339 ) of the randomised and exposed patients for whom compliance data were available in the placebo, $5 \mathrm{mg} / \mathrm{day}$, and $20 \mathrm{mg} /$ day groups, respectively, achieved compliance of $80 \%$ or more with the study medication.

Weight loss was significantly greater with both doses of rimonabant than with placebo, independent of age and sex ( $\mathrm{p}=0.01$ for $5 \mathrm{mg} v s$ placebo, $\mathrm{p}<0.0001$ for $20 \mathrm{mg} v s$ placebo; table 2 and figure 2 ). The placebo-corrected weight loss after 1 year of treatment with $20 \mathrm{mg}$ /day rimonabant was $3.9 \mathrm{~kg}$ (SD 0.3); placebo-subtracted losses were $4.3 \mathrm{~kg}(0 \cdot 4)$ in patients treated with metformin and $3 \cdot 1 \mathrm{~kg}(0 \cdot 5)$ in those treated with sulfonylurea after 1 year of $20 \mathrm{mg}$ /day rimonabant ( $<0.0001$ for both). The number of patients achieving weight loss of $5 \%$ or more 
and $10 \%$ or more at the last follow-up visit was also significantly greater in both groups receiving rimonabant than in the placebo group ( $\geq 5 \%$ loss: $\mathrm{p}=0.02$ for $5 \mathrm{mg}$ and $\mathrm{p}<0.0001$ for $20 \mathrm{mg} ; \geq 10 \%$ loss: $\mathrm{p}=0.01 \mathrm{for} 5 \mathrm{mg}$ and $\mathrm{p}<0.0001$ for $20 \mathrm{mg}$; table 2). Waist circumference was significantly lower with both doses of rimonabant than with placebo ( $\mathrm{p}=0.02$ for $5 \mathrm{mg}, \mathrm{p}<0.0001$ for $20 \mathrm{mg}$; table 2 and figure $2 \mathrm{~B}$ ).

Table 1: Characteristics of participants

\begin{tabular}{|c|c|c|c|}
\hline Demographics at screening* & $\begin{array}{l}\text { Placebo group } \\
\quad(n=348)\end{array}$ & $\begin{array}{c}5 \mathrm{mg} / \text { day rimonabant group } \\
(\mathrm{n}=358)\end{array}$ & $\begin{array}{l}20 \text { mg/day rimonabant } \\
\text { group }(n=339)\end{array}$ \\
\hline Age (years) & $54 \cdot 8(8 \cdot 6)$ & $55 \cdot 9(8 \cdot 6)$ & $56 \cdot 0(8 \cdot 5)$ \\
\hline Sex $(\%$ male $)$ & $159(46 \%)$ & $186(52 \%)$ & $168(50 \%)$ \\
\hline \multicolumn{4}{|l|}{ Race } \\
\hline White (\%) & $308(89 \%)$ & $315(88 \%)$ & $302(89 \%)$ \\
\hline Black (\%) & $18(5 \%)$ & $20(6 \%)$ & $19(6 \%)$ \\
\hline Weight (kg) & $97 \cdot 5(15 \cdot 1)$ & $98 \cdot 7(15 \cdot 1)$ & $97 \cdot 1(14 \cdot 4)$ \\
\hline \multicolumn{4}{|l|}{ Waist (cm) } \\
\hline Male & $114 \cdot 7(10 \cdot 6)$ & $113 \cdot 6(10 \cdot 6)$ & $112 \cdot 9(10 \cdot 0)$ \\
\hline Female & $106 \cdot 5(10 \cdot 1)$ & $107 \cdot 1(10 \cdot 2)$ & $107 \cdot 0(10 \cdot 2)$ \\
\hline Body-mass index $\left(\mathrm{kg} / \mathrm{m}^{2}\right)$ & $34 \cdot 2(3 \cdot 6)$ & $34 \cdot 4(3 \cdot 6)$ & $34 \cdot 1(3 \cdot 6)$ \\
\hline $\mathrm{HbA}_{1 \mathrm{c}}(\%)$ & $7 \cdot 5 \%(0 \cdot 9)$ & $7 \cdot 5 \%(0 \cdot 8)$ & $7 \cdot 5 \%(0 \cdot 8)$ \\
\hline Current smokers (\%) & $51(15 \%)$ & $43(12 \%)$ & $30(9 \%)$ \\
\hline Hypertension $(\%) \dagger$ & $206(59 \%)$ & $218(61 \%)$ & $216(64 \%)$ \\
\hline Dyslipidaemia(\%) $\$$ & $186(53 \%)$ & $202(56 \%)$ & $193(57 \%)$ \\
\hline \multicolumn{4}{|l|}{ Antidiabetic treatment } \\
\hline Metformin & $230(66 \%)$ & $230(64 \%)$ & $218(64 \%)$ \\
\hline Sulphonylureas & $118(34 \%)$ & $128(36 \%)$ & $121(36 \%)$ \\
\hline \multicolumn{4}{|l|}{ Efficacy at baseline } \\
\hline Weight $(\mathrm{kg})$ & $96 \cdot 0(15 \cdot 1)$ & $97 \cdot 2(14 \cdot 8)$ & $95 \cdot 7(14 \cdot 2)$ \\
\hline \multicolumn{4}{|l|}{ Waist (cm) } \\
\hline Male & $113 \cdot 7(11 \cdot 0)$ & $112 \cdot 0(10 \cdot 5)$ & $111 \cdot 3(9 \cdot 6)$ \\
\hline Female & $105 \cdot 3(10 \cdot 6)$ & $106 \cdot 4(10 \cdot 1)$ & $106 \cdot 0(9 \cdot 9)$ \\
\hline $\mathrm{HbA}_{1 \mathrm{c}}(\%)$ & $7 \cdot 2 \%(0 \cdot 9)$ & $7 \cdot 3 \%(0 \cdot 8)$ & $7 \cdot 3 \%(0 \cdot 8)$ \\
\hline Fasting glucose $(\mathrm{mmol} / \mathrm{L})$ & $8 \cdot 2(2 \cdot 2)$ & $8 \cdot 2(1 \cdot 8)$ & $8 \cdot 5(2 \cdot 2)$ \\
\hline Fasting insulin $(\mu \mathrm{lU} / \mathrm{mL})$ & $16 \cdot 0(13 \cdot 3)$ & $14 \cdot 9(9 \cdot 3)$ & $15 \cdot 5(11 \cdot 3)$ \\
\hline HOMA-IR & $5 \cdot 8(7 \cdot 3)$ & $5 \cdot 3(3 \cdot 5)$ & $5 \cdot 9(5 \cdot 0)$ \\
\hline $\begin{array}{l}\text { Triglycerides }(\mathrm{mmol} / \mathrm{L}) \mathrm{HDL} \text { cholesterol } \\
(\mathrm{mmol} / \mathrm{L})\end{array}$ & $1.93(1.05)$ & $1.95(1.01)$ & $2 \cdot 12(1 \cdot 29)$ \\
\hline Men & $1 \cdot 06(0 \cdot 23)$ & $1 \cdot 06(0 \cdot 22)$ & $1 \cdot 08(0 \cdot 22)$ \\
\hline Women & $1 \cdot 26(0 \cdot 28)$ & $1 \cdot 28(0 \cdot 28)$ & $1 \cdot 24(0 \cdot 28)$ \\
\hline LDL cholesterol (mmol/L) & $2 \cdot 99(0 \cdot 80)$ & $2 \cdot 98(0 \cdot 80)$ & $2 \cdot 99(0 \cdot 82)$ \\
\hline Total cholesterol $(\mathrm{mmol} / \mathrm{L})$ & $5 \cdot 00(0 \cdot 96)$ & $499(0 \cdot 97)$ & $5.06(0.97)$ \\
\hline Total cholesterol/HDL cholesterol & $4 \cdot 48(1 \cdot 17)$ & $4 \cdot 46(1 \cdot 20)$ & $4 \cdot 52(1 \cdot 19)$ \\
\hline Non-HDL cholesterol (mmol/L) & $3 \cdot 83(0 \cdot 92)$ & $3 \cdot 83(0 \cdot 2)$ & $3 \cdot 89(0 \cdot 95)$ \\
\hline Metabolic syndrome $\S$ & $271(79 \%)$ & $276(80 \%)$ & $267(79 \%)$ \\
\hline Supine systolic blood pressure (mm Hg) & $128 \cdot 7(13 \cdot 1)$ & $130 \cdot 9(13 \cdot 4)$ & $130 \cdot 3(12 \cdot 5)$ \\
\hline Supine diastolic blood pressure (mm Hg) & $78 \cdot 8(7 \cdot 8)$ & $79 \cdot 0(7 \cdot 9)$ & $79 \cdot 0(7 \cdot 8)$ \\
\hline hsCRP (mg/L) & $6 \cdot 3(8 \cdot 1)$ & $5 \cdot 9(7 \cdot 3)$ & $5 \cdot 4(6 \cdot 5)$ \\
\hline Leptin (ng/mL) & $16(8 \cdot 7)$ & $16(9 \cdot 3)$ & $16(9 \cdot 1)$ \\
\hline \multicolumn{4}{|l|}{ Safety at baseline } \\
\hline Heart rate (bpm) & $67 \cdot 0(10 \cdot 3)$ & $64 \cdot 8(9 \cdot 8)$ & $68 \cdot 5(10 \cdot 6)$ \\
\hline $\mathrm{QTcF}(\mathrm{ms}) \boldsymbol{\Phi}$ & $406 \cdot 0(19 \cdot 1)$ & $406 \cdot 0(21 \cdot 1)$ & $407 \cdot 4(18 \cdot 1)$ \\
\hline HAD/depression\| & $3 \cdot 1(2 \cdot 8)$ & $2 \cdot 8(2 \cdot 6)$ & $3 \cdot 1(2 \cdot 9)$ \\
\hline HAD/anxiety\| & $5 \cdot 2(3 \cdot 4)$ & $4 \cdot 9(3 \cdot 2)$ & $5 \cdot 1(3 \cdot 6)$ \\
\hline
\end{tabular}

Data are number $(\%)$ or mean (SD). *Screening data split into treatment groups retrospectively after randomisation, $\dagger$ Defined as systolic blood pressure $\geq 130 \mathrm{~mm} \mathrm{Hg}$ or supine diastolic blood pressure $\geq 85 \mathrm{~mm} \mathrm{Hg}$, or both; overall $93 \%$ of patients with hypertension were treated. † Defined for men as LDL-cholesterol concentration $\geq 3.36 \mathrm{mmol} / \mathrm{L}$, or H DL-cholesterol concentration $<1 \cdot 03 \mathrm{mmol} / \mathrm{L}$ for men and $<1 \cdot 3$ $\mathrm{mmol} / \mathrm{L}$ for women, or triglyceride concentration $\geq 1.69 \mathrm{mmol} / \mathrm{L}$; overall $65 \%$ of patients with dyslipidaemia were treated. $\S$ Patients had metabolic syndrome as detected according to NCEP-ATP III. ${ }^{2}$ Data on metabolic syndrome at baseline available for 342,347 , and 337 patients in the placebo, $5 \mathrm{mg}$, and $20 \mathrm{mg}$ groups, respectively. $\uparrow \mathrm{QT}$ interval corrected for heart rate. $\|$ HAD=Hospital Anxiety and Depression. The HAD scale consists of 14 items measuring the level of anxiety and depression in two separate subscales. Scale scores range from 0 (no symptoms) to 21 (maximum distress) for both depression and anxiety and is interpreted with the following cut points: $0-7=$ normal, 8 $10=$ mild disturbance (probable case), $\geq 11=$ moderate to mood disturbance (definite case). 
Table 2: Changes in weight and risk factors

\begin{tabular}{|c|c|c|c|c|c|}
\hline Weight & Placebo & $\begin{array}{l}5 \mathrm{mg} / \mathrm{day} \\
\text { rimonabant }\end{array}$ & $\begin{array}{l}20 \mathrm{mg} / \mathrm{day} \\
\text { rimonabant }\end{array}$ & $\begin{array}{l}\text { p value } \\
\text { (5 mg vs } \\
\text { placebo) }\end{array}$ & $\begin{array}{l}\text { p value } \\
\text { (20 mg vs } \\
\text { placebo) }\end{array}$ \\
\hline Number of patients with data at last visit & 345 & 355 & 336 & & \\
\hline Change from baseline $(\mathrm{kg})$ & $-14(3 \cdot 6)$ & $-2 \cdot 3(4 \cdot 2)$ & $-5 \cdot 3(5 \cdot 2)$ & $0 \cdot 01$ & $<0 \cdot 0001$ \\
\hline$\geq 5 \%$ weight loss & $50(14 \cdot 5 \%)$ & $77(21 \cdot 7 \%)$ & $166(49 \cdot 4 \%)$ & $0 \cdot 02$ & $<0 \cdot 0001$ \\
\hline$\geq 10 \%$ weight loss & $7(2 \cdot 0 \%)$ & $22(6 \cdot 2 \%)$ & $55(16 \cdot 4 \%)$ & $0 \cdot 01$ & $<0 \cdot 0001$ \\
\hline \multicolumn{6}{|l|}{ Waist circumference } \\
\hline Number of patients with data at last visit & 344 & 355 & 336 & & \\
\hline Change from baseline $(\mathrm{cm})$ & $-1 \cdot 9(5 \cdot 5)$ & $-2 \cdot 9(5 \cdot 6)$ & $-5 \cdot 2(6 \cdot 1)$ & $0 \cdot 02$ & $<0 \cdot 0001$ \\
\hline \multicolumn{6}{|l|}{$\mathrm{HbA}_{1 \mathrm{c}}$} \\
\hline Number of patients with data at last visit & 317 & 330 & 315 & & \\
\hline Change from baseline $(\%)$ & $0 \cdot 1 \%(1 \cdot 0)$ & $-0 \cdot 1 \%(1 \cdot 0)$ & $-0 \cdot 6 \%(0 \cdot 8)$ & $0 \cdot 03$ & $<0 \cdot 0001$ \\
\hline Patients that achieved $\mathrm{HbA}_{1 \mathrm{c}}<6.5 \%$ & $66(21 \%)$ & $78(24 \%)$ & $135(43 \%)$ & $0 \cdot 39$ & $<0 \cdot 0001$ \\
\hline Patients that achieved $\mathrm{HbA}_{1 \mathrm{c}}<7 \%$ & $151(48 \%)$ & $168(51 \%)$ & $214(68 \%)$ & $0 \cdot 40$ & $<0 \cdot 0001$ \\
\hline $\begin{array}{l}\text { Change from baseline in patients taking } \\
\text { metformin* }(\%)\end{array}$ & $0 \cdot 1 \%(1 \cdot 0)$ & $-0 \cdot 1 \%(1 \cdot 1)$ & $-0 \cdot 6 \%(0 \cdot 8)$ & $0 \cdot 19$ & $<0 \cdot 0001$ \\
\hline $\begin{array}{l}\text { Change from baseline in patients taking } \\
\text { sulphonylureas } \dagger(\%)\end{array}$ & $0 \cdot 1 \%(1 \cdot 1)$ & $-0 \cdot 1 \%(0 \cdot 9)$ & $-0 \cdot 5 \%(0 \cdot 8)$ & $0 \cdot 07$ & $<0 \cdot 0001$ \\
\hline \multicolumn{6}{|l|}{ Fasting glucose concentration } \\
\hline Number of patients with data at last visit & 317 & 331 & 317 & & \\
\hline Change from baseline $(\mathrm{mmol} / \mathrm{L})$ & $0 \cdot 33(2 \cdot 32)$ & $0 \cdot 30(2 \cdot 06)$ & $-0 \cdot 64(1 \cdot 96)$ & $0 \cdot 86$ & $<0 \cdot 0001$ \\
\hline \multicolumn{6}{|l|}{ Fasting insulin } \\
\hline Number of patients with data at last visit & 314 & 328 & 311 & & \\
\hline Change from baseline $(\mu \mathrm{lU} / \mathrm{mL})$ & $0 \cdot 4(14 \cdot 8)$ & $0 \cdot 7(9 \cdot 0)$ & $-0 \cdot 7(9 \cdot 9)$ & $0 \cdot 76$ & $0 \cdot 25$ \\
\hline \multicolumn{6}{|l|}{ HOMA-IR } \\
\hline Number of patients with data at last visit & 308 & 319 & 309 & & \\
\hline Change from baseline & $0 \cdot 6(8 \cdot 9)$ & $0 \cdot 6(4 \cdot 2)$ & $-0 \cdot 5(5 \cdot 7)$ & $0 \cdot 97$ & $0 \cdot 03$ \\
\hline \multicolumn{6}{|l|}{ HDL cholesterol $\uparrow$} \\
\hline Number of patients with data at last visit & 314 & 331 & 318 & & \\
\hline Change from baseline $(\mathrm{mmol} / \mathrm{L})$ & $0 \cdot 07(0 \cdot 15)$ & $0 \cdot 11(0 \cdot 19)$ & $0 \cdot 17(0 \cdot 20)$ & $0 \cdot 02$ & $<0 \cdot 0001$ \\
\hline Change from baseline $(\%)$ & $7 \cdot 1 \%(13 \cdot 5)$ & $9 \cdot 2 \%(15 \cdot 8)$ & $15 \cdot 4 \%(17 \cdot 4)$ & $0 \cdot 08$ & $<0 \cdot 0001$ \\
\hline \multicolumn{6}{|l|}{ Triglycerides +} \\
\hline Number of patients with data at last visit & 314 & 330 & 317 & & \\
\hline Change from baseline $(\mathrm{mmol} / \mathrm{L})$ & $0 \cdot 04(0 \cdot 87)$ & $-0 \cdot 01(0 \cdot 79)$ & $-0 \cdot 35(1 \cdot 28)$ & $0 \cdot 50$ & $<0 \cdot 0001$ \\
\hline Change from baseline $(\%)$ & $7 \cdot 3 \%(43 \cdot 0)$ & $1 \cdot 3 \%(35 \cdot 1)$ & $-9 \cdot 1 \%(44 \cdot 3)$ & $0 \cdot 07$ & $<0 \cdot 0001$ \\
\hline \multicolumn{6}{|l|}{ Total cholesterol/HDL cholesterol ratio } \\
\hline Number of patients with data at last visit & 314 & 330 & 317 & & \\
\hline Change from baseline & $-0 \cdot 16(0 \cdot 79)$ & $-0 \cdot 23(0 \cdot 80)$ & $-0 \cdot 51(0 \cdot 82)$ & $0 \cdot 27$ & $<0 \cdot 0001$ \\
\hline \multicolumn{6}{|l|}{ Change in non-HDL cholesterol $\uparrow$} \\
\hline Number of patients with data at last visit & 314 & 330 & 317 & & \\
\hline Change from baseline $(\mathrm{mmol} / \mathrm{L})$ & $0 \cdot 02(0 \cdot 85)$ & $0 \cdot 00(0 \cdot 75)$ & $-0 \cdot 13(0 \cdot 80)$ & $0 \cdot 70$ & $0 \cdot 02$ \\
\hline Change from baseline $(\%)$ & $2 \cdot 5 \%(22 \cdot 5)$ & $2 \cdot 0 \%(21 \cdot 1)$ & $-1 \cdot 8 \%(21 \cdot 0)$ & $0 \cdot 75$ & $0 \cdot 01$ \\
\hline \multicolumn{6}{|l|}{ Total cholesterolt } \\
\hline Number of patients with data at last visit & 314 & 331 & 317 & & \\
\hline Change from baseline $(\mathrm{mmol} / \mathrm{L})$ & $0 \cdot 10(0 \cdot 88)$ & $0 \cdot 11(0 \cdot 76)$ & $0 \cdot 04(0 \cdot 82)$ & $0 \cdot 90$ & $0 \cdot 36$ \\
\hline Change from baseline $(\%)$ & $3 \cdot 3 \%(17 \cdot 7)$ & $3 \cdot 3 \%(16 \cdot 2)$ & $2 \cdot 0 \%(16 \cdot 5)$ & $0 \cdot 98$ & $0 \cdot 32$ \\
\hline \multicolumn{6}{|l|}{ LDL cholesterol } \\
\hline Number of patients with data at last visit & 314 & 331 & 317 & & \\
\hline Change from baseline $(\mathrm{mmol} / \mathrm{L})$ & $0 \cdot 13(0 \cdot 76)$ & $0 \cdot 13(0 \cdot 66)$ & $0 \cdot 09(0 \cdot 79)$ & $0 \cdot 99$ & $0 \cdot 52$ \\
\hline Change from baseline $(\%)$ & $7 \cdot 2 \%(26 \cdot 3)$ & $7 \cdot 5 \%(26 \cdot 8)$ & $6 \cdot 9 \%(34 \cdot 5)$ & $0 \cdot 89$ & $0 \cdot 90$ \\
\hline \multicolumn{6}{|l|}{ Metabolic syndrome } \\
\hline Number of patients with data at last visit & 316 & 331 & 318 & & \\
\hline Improvement at 1 year & $44 / 251(18 \%)$ & $57 / 260(22 \%)$ & $66 / 252(26 \%)$ & $0 \cdot 21$ & $0 \cdot 02$ \\
\hline Development at 1 year & $25 / 65(38 \%)$ & $21 / 71(30 \%)$ & $18 / 66(27 \%)$ & $0 \cdot 28$ & $0 \cdot 17$ \\
\hline \multicolumn{6}{|l|}{ Supine systolic blood pressure } \\
\hline Number of patients with data at last visit & 345 & 355 & 336 & & \\
\hline Change from baseline $(\mathrm{mm} \mathrm{Hg})$ & $1 \cdot 6(13 \cdot 2)$ & $-0 \cdot 4(12 \cdot 9)$ & $-0 \cdot 8(12 \cdot 8)$ & $0 \cdot 04$ & $0 \cdot 02$ \\
\hline \multicolumn{6}{|l|}{ Supine diastolic blood pressure } \\
\hline Number of patients with data at last visit & 345 & 355 & 336 & & \\
\hline
\end{tabular}




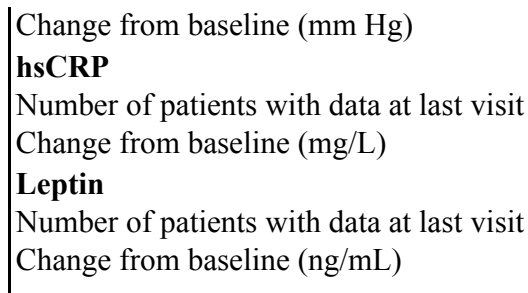

$-0 \cdot 7(8 \cdot 4)$<smiles>[AsH2][AsH2]</smiles>

$-1 \cdot 9(8 \cdot 2)$

308

$-0 \cdot 0(10 \cdot 0)$

323

$-0 \cdot 5(5 \cdot 8)$

313

$-1 \cdot 4(5 \cdot 2)$

$0 \cdot 48$

290

$3 \cdot 1(7 \cdot 5)$
308

$1 \cdot 9(6 \cdot 1)$
294

$-0 \cdot 3(6 \cdot 0)$
$0 \cdot 06$

$0 \cdot 02$

$<0 \cdot 0001$

Data are mean (SD) or $\mathrm{n} / \mathrm{N}(\%)$, unless otherwise indicated. HOMA-IR=Homoeostasis Model of Assessment of insulin resistance. ${ }^{*} \mathrm{n}=211$, $\mathrm{n}=209$, and $\mathrm{n}=204$ in the placebo, $5 \mathrm{mg} /$ day, and $20 \mathrm{mg}$ /day rimonabant groups, respectively, at the end of study. $\dagger \mathrm{n}=106, \mathrm{n}=121, \mathrm{n}=111 \mathrm{in}$ the placebo, $5 \mathrm{mg} / \mathrm{day}$, and $20 \mathrm{mg}$ /day rimonabant groups, respectively, at the end of study. $\ddagger$ Analyses of cholesterol (total, LDL, HDL, and non-HDL) and triglycerides were done on percent changes from baseline.

$\mathrm{HbA}_{\mathrm{lc}}$ levels were lower with both doses of rimonabant than with placebo ( $\mathrm{p}=0.03$ for $5 \mathrm{mg}$ and $\mathrm{p}<0.0001$ for 20 $\mathrm{mg}$; table 2 and figure $3 \mathrm{~A}$ and $\mathrm{B}$ ) with a sustained decline in the $20 \mathrm{mg} /$ day rimonabant group (figure 3A). Treatment with metformin or sulphonylurea did not affect $\mathrm{HbA}_{\mathrm{lc}}$ levels (table 2). More patients in the $20 \mathrm{mg} / \mathrm{day}$ rimonabant group reached an $\mathrm{HbA}_{\mathrm{lc}}$ target of less than $6 \cdot 5 \%{ }^{30}$ and less than $7 \%{ }^{31}$ than did those in the placebo group ( $p<0.0001$ for both target levels; table 2). The observed effects of $20 \mathrm{mg}$ /day rimonabant on Hb $\mathrm{A}_{\mathrm{lc}} \mathrm{were}$ about twice that attributable to concurrent weight loss alone after adjustment with ANCOVA (figure 3C). For example, of the observed placebo-subtracted $0 \cdot 7 \%$ reduction in $\mathrm{HbA}_{\mathrm{lc}}$ with $20 \mathrm{mg}$ /day rimonabant, $0 \cdot 4 \%$ (SD $0 \cdot 1)$ remained after weight-loss adjustment, equivalent to $57 \%(10)$ of the overall response $(\mathrm{p}<0 \cdot 0001)$. In the 20 $\mathrm{mg} /$ day rimonabant group more patients needed downward adjustment of their antidiabetic medication than did those in the placebo group (table 3).

Improvements in fasting glucose concentrations and HOMA-IR were greater in the $20 \mathrm{mg} /$ day rimonabant group than in the placebo group ( $<<0 \cdot 0001$ and $p=0 \cdot 03$, respectively; table 2$)$. HDL cholesterol, triglyceride, and nonHDL-cholesterol concentrations also improved more with $20 \mathrm{mg}$ /day rimonabant than with placebo $(\mathrm{p}<0.0001$ for all; table 2 and figure 2C and D). The residual effect on HDL-cholesterol concentration of $20 \mathrm{mg} / \mathrm{day}$ rimonabant was $57 \%$ (14) of the observed effect after adjustment for weight loss $(\rho<0 \cdot 0001)$. The residual effect on triglyceride concentration after adjustment for weight loss was 36\% (20) of the observed effect, which was not significant $(\mathrm{p}=0.08)$. The persisting prevalence of the metabolic syndrome was lower in the $20 \mathrm{mg} / \mathrm{day}$ rimonabant group than in the placebo group at 1 year $(\mathrm{p}=0 \cdot 02$; table 2$)$. Supine systolic blood pressure was lower in both rimonabant groups than it was in the placebo group ( $\mathrm{p}=0.04$ for $5 \mathrm{mg}, \mathrm{p}=0.02$ for $20 \mathrm{mg}$; table 2). However, the residual effect on supine systolic blood pressure after adjustment for weight loss was $48 \%$ (42) of the observed effect, which was not significant $(\mathrm{p}=0 \cdot 30)$. The prevalence of hypertension in the $20 \mathrm{mg} / \mathrm{day}$ rimonabant group was much the same as that in the placebo group and it did not differ between baseline and 1 year of treatment (54.8\% vs 53.9\%, respectively, in the $20 \mathrm{mg}$ /day group). The decrease in hsCRP levels was greater in the $20 \mathrm{mg} /$ day rimonabant group than it was in the placebo group $(\mathrm{p}=0 \cdot 02$; table 2$)$. Change in fibrinogen concentrations were much the same in all three groups (data not shown). Leptin levels-a marker of fat mass - were lower in the $20 \mathrm{mg}$ /day rimonabant group than they were in the placebo group $(\mathrm{p}<0 \cdot 0001$; table 2).

Improvements were seen for all food behaviour parameters in the $20 \mathrm{mg} /$ day rimonabant group at 1 year. Patients in the $20 \mathrm{mg}$ /day rimonabant group reported less appetite $(\mathrm{p}<0 \cdot 0001)$, easier to follow the diet $(\mathrm{p}<0 \cdot 0001)$, less desire for high fat foods $(p=0 \cdot 0003)$, and less desire for sweets $(p=0 \cdot 04)$ than did those in the placebo group (data not shown). A number of exploratory secondary parameters were investigated as per protocol. A greater improvement in physical functioning (as assessed by SF36; $\mathrm{p}=0 \cdot 012$; data not shown) and a greater impairment in mental health score $(p=0.022)$ were recorded at 1 year in the $20 \mathrm{mg} /$ day rimonabant group than in the placebo group (data not shown). Furthermore, more patients on $20 \mathrm{mg}$ /day rimonabant reported being "very" or "exceptionally" satisfied at 1 year than did patients on placebo $(\mathrm{p}=0.001)$, as assessed by a patient's satisfaction scale (data not shown). Health-related quality of life was specifically assessed with IWQoL-Lite. A greater improvement at 1 year in the physical function $(p=0.002)$ and self-esteem domains $(p=0.004)$ and in the total IWQoL-Lite score $(p=0.006)$ was noted in the $20 \mathrm{mg}$ /day rimonabant group than in the placebo group (data not shown). 
Figure 2: Changes in weight, waist, HDL cholesterol, and triglycerides (A) Mean (SE) change from baseline in bodyweight over 1 year; last observation carried forward (LOCF), baseline observation carried forward (BOCF), and repeated measures $(R M),{ }^{*} p<0 \cdot 001, t p=0 \cdot 01, t p=0.03$ vs placebo. (B) Mean (SE) change from baseline in waist circumference over 1 year; LOCF, BOCF, and $R M$. ${ }^{*} p<0 \cdot 001, \dagger p=0 \cdot 02, \stackrel{t}{t}=0.03$ vs placebo. (C) Mean (SE) percentage change from baseline in HDL-cholesterol concentration over 1 year; $L O C F, B O C F$, and $R M .{ }^{*} p<0 \cdot 001$, $\neq p=0.05 \mathrm{vs}$ placebo. (D) Mean (SE) percentage change from baseline in triglyceride levels over 1 year; $L O C F, B O C F$, and $R M .{ }^{*} p<0 \cdot 001$ vs placebo.
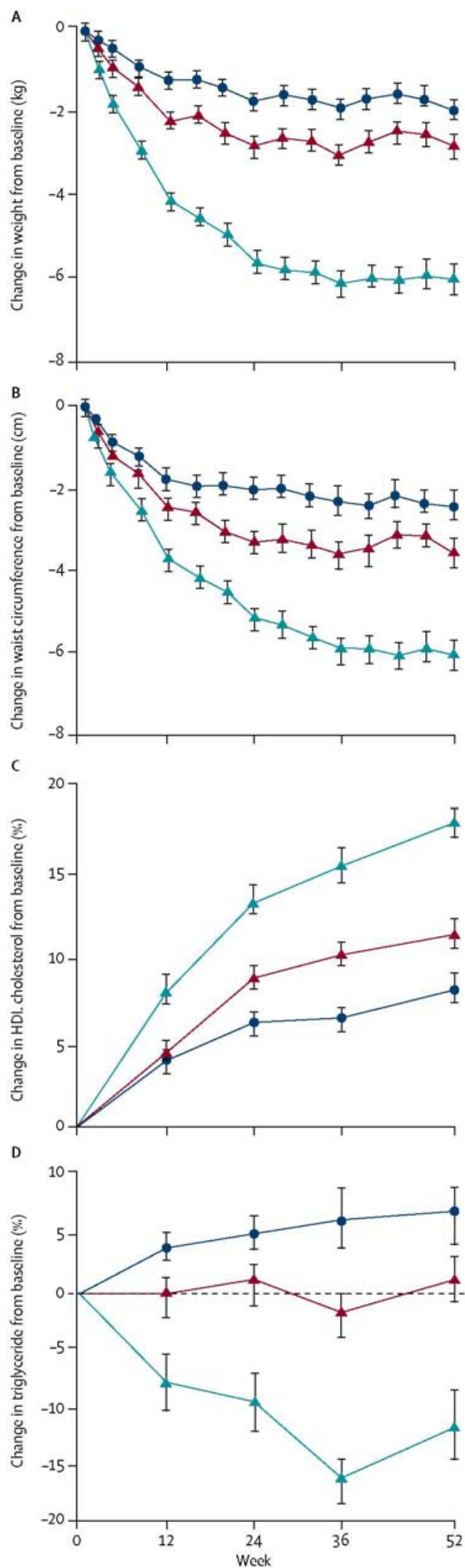
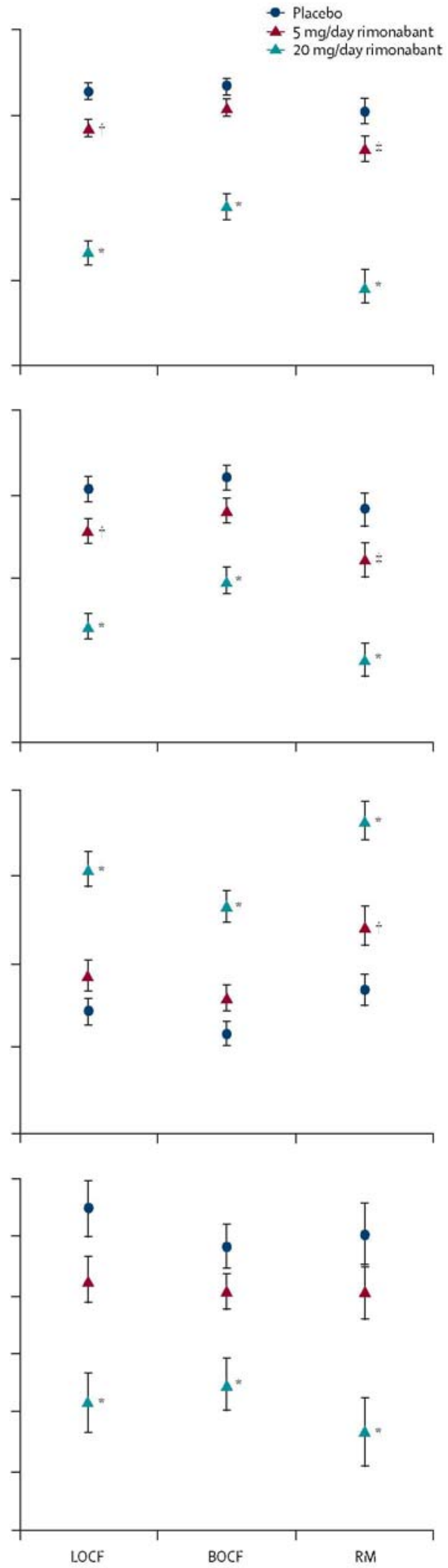
Figure 3: Changes in $\mathrm{HbA}_{1 c}$ levels (A) Mean (SE) change from baseline in $\mathrm{HbA}_{1 \mathrm{c}}$ levels over 1 year. (B) Mean (SE) change from baseline in $\mathrm{HbA}_{\mathrm{lc}}$ levels: last observation carried forward (LOCF), baseline observation carried forward (BOCF), and repeated measures (RM) * $\mathrm{p}<0 \cdot 0001, \dagger \mathrm{p}=0 \cdot 03, \vdots \mathrm{p}=0 \cdot 04, \S \mathrm{p}=0.05$ vs placebo. (C) Linear regression analysis between $\mathrm{HbA}_{\mathrm{lc}}$ changes and bodyweight changes, excluding patients with extreme weight loss ( $\geq 11.2 \mathrm{~kg}$ ), in patients receiving placebo or $20 \mathrm{mg} /$ day rimonabant. The weight change data from lowest to highest was divided into ten groups with about equal sample size (deciles) and within each decile the mean weight change and the mean change in $\mathrm{HbA}_{1 \mathrm{c}}$ was calculated The pairs of mean changes (weight, $\mathrm{HbA}_{\mathrm{lc}}$ ) were plotted along with the regression line to illustrate the relation between weight loss and $\mathrm{HbA}_{\mathrm{lc}}$.
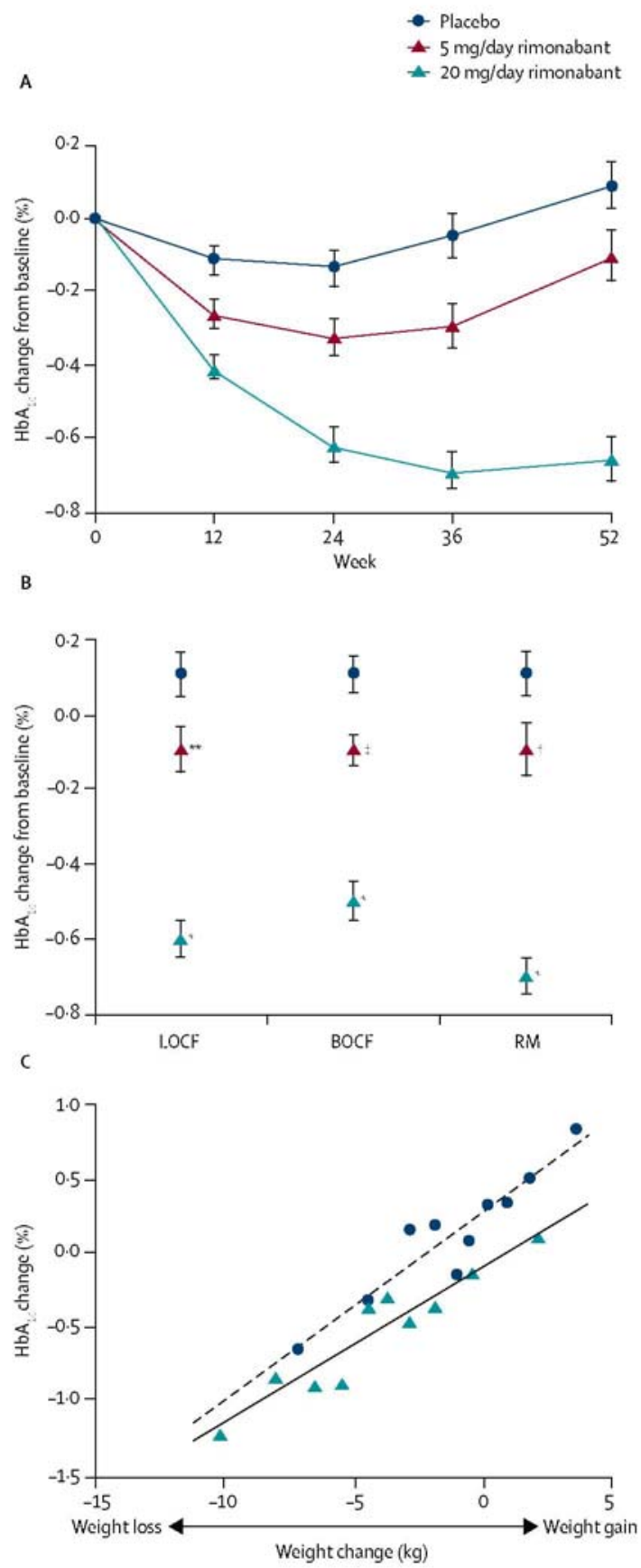

A slightly greater proportion of patients in the rimonabant treatment groups experienced adverse events than did those in the placebo group (table 4). The most common adverse events, occurring in $5 \%$ or more rimonabanttreated patients, were nausea, diarrhoea, vomiting, dizziness, hypoglycaemia, fatigue, and anxiety (table 4); these were generally mild or moderate, transient and self-limited, and seen early in the treatment period. In the 20 $\mathrm{mg}$ /day rimonabant group, hypoglycaemia was reported more frequently in diabetic patients treated with sulphonylureas than in those given metformin, but only one case led to treatment discontinuation. 
Although overall discontinuation rates were much the same in all groups, discontinuations due to adverse events were more frequent in the $20 \mathrm{mg}$ /day and $5 \mathrm{mg} /$ day rimonabant groups than they were in the placebo group (table 4). Dropouts due to adverse events in the $20 \mathrm{mg} /$ day group were much the same in patients who lost weight ( $-5 \mathrm{~kg}$ or more) as in those who gained weight $(\geq 0 \mathrm{~kg})-10 \cdot 6 \%$ (16 of 151 patients) and $12 \cdot 8 \%$ (5 of 39 patients), respectively. The most common adverse events that led to premature study discontinuation in the 20 $\mathrm{mg}$ /day rimonabant group were depressed mood disorders, nausea, and dizziness (table 4). However, no serious adverse events linked to psychiatric disorders were recorded in either rimonabant group.

Cardiovascular safety endpoint measures and HAD depression and anxiety subscores were much the same across the three treatment arms at baseline and at 1 year (table 1 and table 4). Although there was a trend towards slight increases in both HAD scores in the $20 \mathrm{mg}$ /day rimonabant group compared with the placebo group, the observed increases should be considered to be marginal.

\section{Discussion}

The main finding of the RIO-Diabetes trial is that $20 \mathrm{mg} /$ day rimonabant for 1 year significantly reduced weight, waist circumference, and $\mathrm{HbA}_{\mathrm{lc}}$ levels and improved a number of cardiovascular and metabolic risk factors in overweight or obese patients with type 2 diabetes that was inadequately controlled by metformin or sulphonylurea. These results extend previous findings in non-diabetic overweight or obese patients to those with type 2 diabetes. ${ }^{17-19}$ Patients with type 2 diabetes are characterised by resistance to weight loss, ${ }^{8}$ overactivity of the endocannabinoid system, ${ }^{16}$ and increased cardiovascular risk, ${ }^{2,3}$ with obesity being deemed to be an additional and independent risk factor. ${ }^{32}$

Treatment with $20 \mathrm{mg}$ /day rimonabant enabled a greater number of patients on monotherapy with metformin or sulphonylurea whose baseline $\mathrm{HbA}_{\mathrm{lc}}$ levels were close to the American Diabetes Association recommended level $(7 \%)$ to attain such a target. ${ }^{31}$ The placebo-corrected reduction in $\mathrm{HbA}_{\mathrm{lc}}$ levels of $0.7 \%$ seen with $20 \mathrm{mg} / \mathrm{day}$ rimonabant is clinically relevant, since every $1 \%$ reduction in $\mathrm{HbA}_{\mathrm{lc}}$ has been shown to be associated with a reduction in risk of $21 \%$ for any endpoint related to diabetes. ${ }^{33}$ For the purpose of comparison, in metformintreated diabetic patients, treatment with twice-daily subcutaneous injection of $10 \mu \mathrm{g}$ exenatide induced a $0 \cdot 86 \%$ placebo-subtracted reduction in $\mathrm{HbA}_{\mathrm{lc}}$ after 30 weeks, a decrease that is close to that recorded with $20 \mathrm{mg} / \mathrm{day}$ rimonabant with baseline $\mathrm{HbA}_{\mathrm{lc}}$ levels above $8 \%{ }^{34}$

Improved glycaemic control has an important beneficial effect on the risk of microvascular and macrovascular complications related to diabetes. ${ }^{33}$ Nevertheless, in recent years considerable emphasis has been placed on aggressive management of multiple cardiovascular and metabolic risk factors in type 2 diabetes patients. ${ }^{35,36} 20$ $\mathrm{mg}$ /day rimonabant improved atherogenic dyslipidaemia and diminished systolic blood pressure in diabetic patients, and also reduced the prevalence of metabolic syndrome, ${ }^{37}$ as already reported in overweight dyslipidaemic non-diabetic patients. ${ }^{19}$ Compared with placebo, $20 \mathrm{mg}$ /day rimonabant also reduced hsCRP levels, an inflammatory biomarker considered to be a moderate predictor of cardiovascular disease. ${ }^{38}$

Table 3: Distribution of dose changes in antidiabetic medications

\begin{tabular}{|c|c|c|c|}
\hline & $\begin{array}{l}\text { Placebo } \\
(n=345)\end{array}$ & $\begin{array}{c}5 \mathrm{mg} / \mathrm{day} \\
\text { rimonabant } \\
(\mathrm{n}=355)^{*}\end{array}$ & $\begin{array}{c}20 \mathrm{mg} / \mathrm{day} \\
\text { rimonabant } \\
(\mathrm{n}=336) \dagger\end{array}$ \\
\hline No change & $268(77 \cdot 7 \%)$ & $279(78 \cdot 6 \%)$ & $255(75 \cdot 9 \%)$ \\
\hline Increase & $44(12 \cdot 8 \%)$ & $49(13 \cdot 8 \%)$ & $38(11 \cdot 3 \%)$ \\
\hline Decrease & $26(7 \cdot 5 \%)$ & $22(6 \cdot 2 \%)$ & $40(11 \cdot 9 \%)$ \\
\hline Another drug added due to insufficient efficacy & $7(2.0 \%)$ & $3(0 \cdot 8 \%)$ & $0(0 \%)$ \\
\hline Another drug added due to other reasons & $0(0 \%)$ & $2(0 \cdot 6 \%)$ & $3(0 \cdot 9 \%)$ \\
\hline
\end{tabular}


Table 4: Safety data at 1 year and adverse events in randomised and exposed patients

\begin{tabular}{|c|c|c|c|}
\hline & Placebo $(n=348)$ & $\begin{array}{l}5 \mathrm{mg} / \mathrm{day} \\
\text { rimonabant } \\
(\mathrm{n}=358)\end{array}$ & $\begin{array}{l}20 \mathrm{mg} / \text { day rimonabant } \\
(\mathrm{n}=339)\end{array}$ \\
\hline \multicolumn{4}{|l|}{ Safety data at 1 year } \\
\hline Overall dropout rate & $117(34 \%)$ & $126(35 \%)$ & $110(32 \%)$ \\
\hline Patients with any adverse event & $276(79 \%)$ & $293(82 \%)$ & $288(85 \%)$ \\
\hline Patients with any serious adverse event* & $15(4 \%)$ & $27(8 \%)$ & $27(8 \%)$ \\
\hline Discontinuations dueto adverse events & $19(5 \%)$ & $28(8 \%)$ & $51(15 \%)$ \\
\hline \multicolumn{4}{|c|}{ Adverse events that led to study discontinuation $\uparrow$} \\
\hline \multicolumn{4}{|c|}{ Psychiatric disorders } \\
\hline Depressed mood disorders & $3(0 \cdot 9 \%)$ & 0 & $11(3 \%)$ \\
\hline Anxiety & 0 & 0 & $2(0 \cdot 6 \%)$ \\
\hline Aggression & 0 & $2(0 \cdot 6 \%)$ & 0 \\
\hline \multicolumn{4}{|l|}{ Nervous system disorders } \\
\hline Headache & $1(0 \cdot 3 \%)$ & $1(0 \cdot 3 \%)$ & $2(0 \cdot 6 \%)$ \\
\hline Dizziness & 0 & 0 & $3(0 \cdot 9 \%)$ \\
\hline Paraesthesia & 0 & 0 & $2(0 \cdot 6 \%)$ \\
\hline \multicolumn{4}{|l|}{ Gastrointestinal disorders } \\
\hline Nausea & $1(0 \cdot 3 \%)$ & 0 & $5(1 \cdot 5 \%)$ \\
\hline Vomiting & 0 & 0 & $2(0 \cdot 6 \%)$ \\
\hline \multicolumn{4}{|l|}{ General disorders } \\
\hline Chest pain & 0 & 0 & $2(0 \cdot 6 \%)$ \\
\hline Asthenia/fatigue & 0 & $2(0 \cdot 6 \%)$ & $1(0 \cdot 3 \%)$ \\
\hline \multicolumn{4}{|c|}{ Adverse events with an incidence of $>5 \%$ in any group } \\
\hline Nausea & $20(6 \%)$ & $22(6 \%)$ & $41(12 \%)$ \\
\hline Nasopharyngitis & $74(21 \%)$ & $59(16 \%)$ & $41(12 \%)$ \\
\hline Dizziness & $17(5 \%)$ & $11(3 \%)$ & $31(9 \%)$ \\
\hline Arthralgia & $28(8 \%)$ & $35(10 \%)$ & $30(9 \%)$ \\
\hline Headache & $32(9 \%)$ & $29(8 \%)$ & $28(8 \%)$ \\
\hline Diarrhoea & $23(7 \%)$ & $22(6 \%)$ & $25(7 \%)$ \\
\hline Back pain & $24(7 \%)$ & $22(6 \%)$ & $24(7 \%)$ \\
\hline Upper respiratory tract infection & $33(9 \%)$ & $28(8 \%)$ & $23(7 \%)$ \\
\hline Vomiting & $8(2 \%)$ & $14(4 \%)$ & $20(6 \%)$ \\
\hline Hypoglycaemia & $6(2 \%)$ & $5(1 \%)$ & $18(5 \%)$ \\
\hline Fatigue & $13(4 \%)$ & $19(5 \%)$ & $18(5 \%)$ \\
\hline Anxiety & $9(3 \%)$ & $4(1 \%)$ & $17(5 \%)$ \\
\hline \multicolumn{4}{|l|}{ Safety endpoints } \\
\hline Heart rate $(\mathrm{bpm}) \ddagger$ & & & 314 \\
\hline Number of patients with data at last visit & 314 & 332 & \\
\hline Year 1 & $67 \cdot 8(10 \cdot 8)$ & $69 \cdot 3(10 \cdot 1)$ & $69 \cdot 5(11 \cdot 4)$ \\
\hline Change from baseline & $0 \cdot 8(8 \cdot 8)$ & $0 \cdot 9(8 \cdot 7)$ & $1 \cdot 0(10 \cdot 2)$ \\
\hline \multicolumn{4}{|l|}{$\mathrm{QTcF}(\mathrm{ms}) \ddagger$} \\
\hline Number of patients with data at last visit & 313 & 331 & 314 \\
\hline Last recorded value & $403 \cdot 9(20 \cdot 1)$ & $404 \cdot 4(19 \cdot 8)$ & $407 \cdot 1(19 \cdot 4)$ \\
\hline Change from baseline & $-2 \cdot 1(16 \cdot 6)$ & $-1 \cdot 6(16 \cdot 3)$ & $-0 \cdot 3(15 \cdot 4)$ \\
\hline \multicolumn{4}{|l|}{$\mathrm{HAD} /$ depression $\nleftarrow$} \\
\hline Number of patients with data at last visit & 279 & 286 & 262 \\
\hline Last recorded value & $2 \cdot 9(3 \cdot 0)$ & $2 \cdot 7(2 \cdot 8)$ & $3 \cdot 3(3 \cdot 3)$ \\
\hline Change from baseline & $-0 \cdot 2(2 \cdot 6)$ & $-0 \cdot 1(2 \cdot 3)$ & $0 \cdot 3(2 \cdot 9)$ \\
\hline \multicolumn{4}{|l|}{ HAD/anxiety } \\
\hline Number of patients with data at last visit & 279 & 285 & 262 \\
\hline Last recorded value & $4 \cdot 9(3 \cdot 6)$ & $4 \cdot 7(3 \cdot 6)$ & $5 \cdot 5(4 \cdot 0)$ \\
\hline Change from baseline & $-0 \cdot 3(3 \cdot 2)$ & $-0 \cdot 1(2 \cdot 7)$ & $0 \cdot 4(3 \cdot 4)$ \\
\hline
\end{tabular}

Data are number (\%) or mean (SD), unless otherwise indicated.*There was one death during the placebo run-in period (cardiac arrest) and four deaths during the double-blind treatment period. One patient in the $5 \mathrm{mg} /$ day rimonabant group died of septic shock 6 months after starting the study treatment, while in the $20 \mathrm{mg}$ /day rimonabant group, one patient was a passenger in a traffic accident (more than 6 months after the start of study treatment) and two metformin-treated patients with multiple risk factors died of a cardiovascular disease (one death 2 months and the other 5 months after the start of study treatment). No causal relation to the study drug was suspected by the investigators for any death. In the overall RIO trial programme ( $\mathrm{n}=6625$; four studies), deaths were equally distributed across groups (four in the placebo group, three in the $5 \mathrm{mg}$ /day rimonabant group, and four in the $20 \mathrm{mg} /$ day rimonabant group), $\uparrow$ According to MedDRA, in at least two patients in any rimonabant group and in main system organ class $(\geq 1 \%)$. One patient can report several events. $\ddagger$ Depressed mood disorders 
corresponded to the MedDRA HLGT term "Depressed mood disorders and disturbances" and consist of depression, major depression, depressed mood, and depressive symptoms.

$57 \%$ of placebo-subtracted effects of $20 \mathrm{mg}$ /day rimonabant on HDL-cholesterol concentrations and $\mathrm{HbA}_{\mathrm{cl}}$ levels were independent of weight loss, consistent with the direct peripheral metabolic effects of the drug. ${ }^{13,15,17,18,39}$ Rimonabant increases the secretion of adiponectin, ${ }^{19}$ an adipokine whose plasma concentrations correlates positively with insulin sensitivity, and levels of which are lower both in obese and type 2 diabetic patients than in lean healthy individuals. ${ }^{40}$ Although low adiponectin levels have been deemed to be a predictor of cardiovascular disease, further studies are needed to confirm this association. ${ }^{41}$ The blockade of $\mathrm{CB}_{1}$ receptors might also inhibit hepatic fatty acid synthesis and hepatic lipid accumulation, which have also been implicated in insulin resistance and dyslipidaemia. ${ }^{14}$

Intentional weight loss in overweight or obese type 2 diabetes patients improves lipid profile, blood pressure, and diabetes control. ${ }^{5}$ Weight loss has been shown to be associated with a reduced mortality risk in observational studies, ${ }^{42}$ although such an association has not been recorded in randomised clinical trials yet. Although only moderate weight loss (5-10\% of bodyweight) is required to improve glycaemic control, weight loss and maintenance of weight loss in patients with type 2 diabetes are generally more difficult than in non-diabetic individuals. ${ }^{8,43}$ Furthermore, most antidiabetic medications (in particular sulphonylureas, thiazolidinediones, and insulin) produce concomitant weight gain. ${ }^{5,31,44}$ In this study, a mean weight loss of $6 \cdot 1 \mathrm{~kg}$ was noted in patients who completed the 1-year treatment with $20 \mathrm{mg}$ /day rimonabant, much the same as that described in the Diabetes Prevention Program (DPP) ${ }^{45}$ in which patients were treated with an intensive lifestyle intervention. However, lifestyle intervention in the DPP was highly demanding and applied to non-diabetic individuals, a population that has less difficulty in losing weight than diabetic patients. ${ }^{8}$ In a study done on 114 obese patients with type 2 diabetes submitted to a 12-month follow-up after a 10-16-week behavioural weight-control programme, only 27 patients $(24 \%)$ who succeeded in obtaining a prolonged weight reduction above $6-9 \mathrm{~kg}$ exhibited a significant reduction in $\mathrm{HbA}_{\mathrm{lc}}$ levels after 1 year. ${ }^{46}$ The authors of a recent consensus statement recognised that for most individuals with type 2 diabetes, lifestyle interventions fail to achieve or maintain metabolic goals, either because of failure to lose weight, weight regain, progressive disease, or a combination of factors. 47

In agreement with previous data, ${ }^{8}$ the placebo-subtracted weight loss at 1 year of treatment with $20 \mathrm{mg} / \mathrm{day}$ rimonabant was $3.9 \mathrm{~kg}$ in the present study in patients with diabetes compared with $4.7 \mathrm{~kg}$ and $5.4 \mathrm{~kg}$ reported in patients without diabetes. ${ }^{17-19}$ Due to its unique mode of action and because of the absence of head-to-head trials, comparison of the results obtained with $20 \mathrm{mg}$ /day rimonabant with those reported with orlistat or sibutramine should be cautious. Nevertheless, this study shows greater weight loss and $\mathrm{HbA}_{\mathrm{lc}}$ reduction than those reported in a recent meta-analysis of sibutramine or orlistat trials in patients with type 2 diabetes and similar demographic characteristics (ie, age, sex, and body-mass index), but higher baseline $\mathrm{HbA}_{\mathrm{lc}}$ levels $(9 \cdot 1-9 \cdot 3 \%$ instead of $7 \cdot 3 \%$ in RIO-Diabetes). ${ }^{48}$

$20 \mathrm{mg}$ /day rimonabant improved health-related quality of life, especially physical functioning, which points to a positive effect of the drug on this health-related concept. ${ }^{21}$ Rimonabant was well tolerated in this study, with adverse events that were generally transient and mild, and much the same as the safety profile reported in nondiabetic patients. ${ }^{17-19}$ The most frequent adverse event that led to premature withdrawal in the $20 \mathrm{mg} / \mathrm{day}$ rimonabant group was the occurrence of self-reported depression. However, objective measures of depression and anxiety from the HAD scales ${ }^{25}$ showed only slight and probably not clinically relevant changes in the 20 $\mathrm{mg}$ /day rimonabant group compared with the placebo group. Nevertheless, in this trial, as in other RIO-trials, ${ }^{17-19}$ patients with severe psychiatric disorders or receiving antidepressants were excluded, so the safety of rimonabant in such individuals remains to be determined.

There are two limitations to our study. First, although consistent with that of previous 1-year studies in overweight or obese patients, ${ }^{49}$ including those done in patients with type 2 diabetes, ${ }^{48}$ the retention rate of about $66 \%$ in all treatment groups might be considered as rather low. One should note that the dropout rate in this study was lower than in previously reported studies with rimonabant in non-diabetic patients. ${ }^{17-19}$ The discontinuation due to reasons other than adverse events was about threefold higher in patients who gained weight than in those who lost weight; this difference was noted in all three treatment arms. Nevertheless, dropouts due to adverse events in the $20 \mathrm{mg}$ /day rimonabant group was much the same in patients who lost weight as in those who gained weight. To take into account the dropout rate, two additional sensitivity analyses, including a repeated measures approach and a BOCF approach, were done, and the results supported the conclusions of the LOCF analysis (figure 2). Second, RIO-Diabetes is a 1-year trial and long-term studies will be 
needed to assess the effect on diabetes-related complications, especially cardiovascular outcomes.

The results of RIO-Diabetes show the therapeutic value of $20 \mathrm{mg} /$ day rimonabant in patients with type 2 diabetes through effective weight loss, reduced abdominal adiposity, a clinically significant reduction in $\mathrm{HbA}_{\mathrm{lc}}$ levels, and improvements in HDL-cholesterol, triglyceride, and hsCRP concentrations, and systolic blood pressure. The improvements in $\mathrm{HbA}_{\mathrm{lc}}$ and $\mathrm{HDL}$-cholesterol concentration levels were twice that expected from the weight loss alone, consistent with the direct peripheral metabolic effects of the drug. These findings support the use of 20 $\mathrm{mg}$ /day rimonabant, in addition to diet and exercise, as a new approach to improve glucose control and reduce a number of cardiovascular and metabolic risk factors in overweight or obese patients with type 2 diabetes that is inadequately controlled with metformin or sulphonylureas.

\section{Contributors}

A J Scheen, N Finer, and L F Van Gaal were involved in the study concept and design. All named authors participated in the study and contributed to the analysis and interpretation of data, and to the drafting, development, and critical revision of the manuscript. The final version of the manuscript was seen and approved by all authors.

\section{Conflict of interest statement}

A J Scheen is a consultant for sanofi-aventis, AstraZeneca, GlaxoSmithKline, and Merck-Santé, and has received lecture fees from sanofi-aventis. N Finer is a consultant for Novarris, Shionogi, Merck, Abbott, sanofi-aventis, Ajinomoto, and GlaxoSmithKline, and has received lecture fees from Abbott, sanofi-aventis, Roche, and NovoNordisk. He has also received grant support from Merck, Novarris, Roche, the EU Framework 6 'Diabesity' grant, Alizyme, Abbott Laboratories, and sanofi-aventis. P Hollander is a consultant for, and has received lecture fees from, sanofi-aventis and Pfizer. M D Jensen is a consultant for sanofi-aventis, Metabolic Pharmaceuticals, Novartis, MetaCure, Shionogi USA, and Merck, and has also received grant support from the US National Institutes of Health. L F Van Gaal is a member of advisory boards for sanofi-aventis, Abbott Pharma, and E Lilly and Co. He has received lecture fees from sanofi-aventis and Abbott Pharma, and has grant support from Fonds voor Wetenschappelfjk Onderzoek (Scientific Research Council, Flanders, Belgium).

\section{RIO-Diabetes StudyGroup}

Data and safety monitoring board-Alain Leizorovicz, Michael Weintraub, Jean-Louis Imbs, Elliot Danforth, David P L Sachs. RIO-Diabetes investigators-Argentina: León Efraín Litwak, Isaac Sinay Mauricio Jadzinsky, Julio Andrés Vallejos, Jorge Noberto Waitman, Jorge Daniel Herrera, Hugo Fideleff; Belgium: Luc Van Gaal, Isabelle Dumont, André Scheen, Francis Duyck, Maximilien Kutnowski; Canada: Jean-Pierre Després, Ronnie Aronson, Robert Verdonk, Bruno St Pierre, Ehud Ur, Ginette Girard, Guy Tellier, Ronald Goldenber, Ben Lasko, Isabelle Perreault, Dominique Garrel, Jiri Frohlich, Geeta Achyuthan, Stuart Ross, Laurie Breger; Czech Republic: Vojtech Hainer, Lubos Sobotka, Zdenek Rusavy, Dalibor Zeman; Finland: Sirkka-Maaret KeinänenKiukaaniemi, Aila Rissanen, Leo Kalevi Niskanen; France: Jean-Louis Schlienger, Daniel Bensoussan, Guillaume Charpentier, Paul Valensi, Charles Couet, Jean-François Luc Gautier, Max Rieu, Christine Lemaire, Patrice Gross, Claude Le Devehat, Nathan Abenhaim, Michel Bismuth, Denis Tamineau, Jean-Marc Kunh; Germany Jens Jordan, Hans-Gerd Dammann, Hendrik Lehnert, Gerhard Klausmann, Peter Weisweiler, Volker Schusdziarra, Annette Chen-Stute, Stephan Maxeiner, Hans-Christoph Treiche; Netherlands: Elisabeth Maria Hubertina Vliegen, M L Drent, R J M Van Leendert, A Van De Wiel, P W E Haeck, M Castro Cabezas, J J C Jonker, H Kopperschaar; Poland: Ida Kinalska, Ewa Semetkowska-Jurkiewicz, Krzysztof Strojek, Jerzy Loba, Joanna Niegowska, Danuta Zytkiewicz-Jaruga; UK: Nicholas Finer, Sudesh Kumar, John Broom, Michael E J Lean, John Wilding, John P D Reckless, Peter Kopelman, Caroline Naik, Jean M K Fraser; USA: M Angeli Adamczyk, Andrew J Ahmann, Jacques D Barth, Jerry Drucker, Brent M Egan, Elizabeth M Gallup, Susan N Greco, Ali Iranmanesh, Adesh K Jain, Michael D Jensen, Rashid K Khairi, Andrew J Lewin, John Paul Lock, N Martin Lunde, Thomas C Marbury, James M McKenney, Patrick M Moriarty, Michael J Noss, Thomas J R O'Barr, Leann Olansky, R Walter Powell, Michele D Reynolds, Jeffrey B Rosen, Simona Scumpia, Norman G Soler, Richard L Weinstein, James H Zavoral, Scherwyn L Schwartz, Theodore Feldman, Timothy R Smith, Mildred V Farmer, W Thomas Garland, Priscilla Hollander, Helmut O Steinberg, Brian D Geary, Amin Radparvar, Stephen W Halpern, Oscar Verzosa, Eli M Roth, Steven Landgarten, Barry C Lubin, Wayne E Larson, F Timm III McCarty, Samuel M Lederman, Dennis C McCluskey, Robert G Cesarec, K Stan Self, Martin J Conway, Stephen S Brady, Ronald V Eliosoff, Andrea J Ramsay, John Rubino, Diane K Smith, Robert 
J Weiss, Alan J Kivitz, H Jackson Downey, Richard E Mills, James W Snyder, Albert J Razzetri, David J Morin, Paul C Tung, Richard V Albery, Scott D Bleser, Donald L Anderson, Curtis J Mello, Lisa Harris, Gerald E Miller, Philip A Snell, Thomas W III Littlejohn, Leah Schmidt, M Scott Touger, Lydia G Corn, Steven K Elliott, Donald Schumacher, William Randall Cox, Barry S Horowitz, Mark S Franklin, E Walter Hood, L Michael Bolognese, Bruce E Henson, Robert Lang, Mark W Layton, Ronald Rapoport, Louis L Shane, Jack D Wahlen, Mohammed Saad, Theodore G Duncan. Acknowledg merits RIO-Diabetes was sponsored by Sanofi Synthelabo Research, a division of Sanofi Synthelabo Inc, a member of the sanofl-aventis group. Editorial support for this article was provided by Sanofi Synthelabo Research.

\section{References}

1 Alexander CM, Landsman PB, Teutsch SM, Haffner SM. NCEP-defined metabolic syndrome, diabetes, and prevalence of coronary heart disease among NHANES III participants age 50 years and older. Diabetes 2003; 52:1210-14.

2 National Cholesterol Education Program (NCEP) Expert Panel on Detection, Evaluation, and Treatment of High Blood Cholesterol in Adults (Adult Treatment Panel III). Third Report of the National Cholesterol Education Program (NCEP) Expert Panel on Detection, Evaluation, and Treatment of High Blood Cholesterol in Adults (Adult Treatment Panel III) final report. Circulation 2002; 106: 3143-421.

3 Haffner SM, Lehto S, Ronnemaa T, Pyorala K, Laakso M. Mortality from coronary heart disease in subjects with type 2 diabetes and in nondiabetic subjects with and without prior myocardial infarction. N Engl J Med 1998; 339: 229-34.

4 Booth GL, Kapral MK, Fung K, Tu JV. Relation between age and cardiovascular disease in men and women with diabetes compared with non-diabetic people: a population-based retrospective cohort study. Lancet 2006; 368: 29-36.

5 Scheen AJ. Current management strategies for coexisting diabetes mellitus and obesity. Drugs 2003; 63: $1165-84$.

6 Yusuf S, Hawken S, Ônpuu S, et al. Obesity and the risk of myocardial infarction in 27000 participants from 52 countries: case-control study. Lancet 2005; 366:1640-49.

7 Chan JM, Rimm EB, Colditz GA, Stampfer MJ, Willett WC. Obesity, fat distribution, and weight gain as risk factors for clinical diabetes in men. Diabetes Care 1994; 17: 961-69.

8 Wing RR, Marcus MD, Epstein LH, Salata R. Type II diabetic subjects lose less weight than their overweight nondiabetic spouses. Diabetes Care 1987; 10: 563-66.

9 Howlett AC, Breivogel CS, Childers SR, Deadwyler SA, Hampson RE, Porrino LJ. Cannabinoid physiology and pharmacology: 30 years of progress. Neuropharmacology 2004; 47 (suppl 1): 345-58.

10 Di Marzo V, Goparaju SK, Wang L, et al. Leptin-regulated endocannabinoids are involved in maintaining food intake. Nature 2001; 410: $822-25$

11 Ravinet Trillou C, Arnone M, Menet C, et al. Anti-obesity effect of SR141716, a CB1 receptor antagonist, in diet-induced obese mice. Am] Physiol Regul Integr Comp Physiol 2003; 284: R345-53.

12 Poirier B, Bidouard JP, Cadrouvele C, et al. The anti-obesity effect of rimonabant is associated with an improved serum lipid profile. Diabetes Obes Metab 2005; 7: 65-72.

13 Bensaid M, Gary-Bobo M, Esclangon A, et al. The cannabinoid CB1 receptor antagonist SR141716 increases Acrp30 mRNA expression in adipose tissue of obese fa/fa rats and in cultured adipocyte cells. Mol Pharmacol 2003; 63: 908-14.

14 Osei-Hyiaman D, DePetrillo M, Pacher P, et al. Endocannabinoid activation at hepatic CB1 receptors stimulates fatty acid synthesis and contributes to diet-induced obesity. J Clin Invest 2005; 115 : 1298-305.

15 Liu YL, Connoley IP, Wilson CA, Stock MJ. Effects of the cannabinoid CB1 receptor antagonist SR141716 on oxygen consumption and soleus muscle glucose uptake in Lep(ob)/Lep(ob) mice. Int J Obes Relat Metab Disord 2005; 29:183-87

16 Marias I, Gonthier MP, Orlando P, et al. Regulation, function, and dysregulation of endocannabinoids in models of adipose and $\beta$ pancreatic cells and in obesity and hyperglycemia. J Clin Endocrinol Metab 2006; 91: 3171-80.

17 Van Gaal LF, Rissanen AM, Scheen AJ, Ziegler O, Rössner S. Effects of the cannabinoid-1 receptor blocker rimonabant on weight reduction and cardiovascular risk factors in overweight patients: 1-year experience from the RIO-Europe study. Lancet 2005; 365: 1389-97

18 Pi-Sunyer FX, Aronne LJ, Heshmati HM, Devin J, Rosenstock J, RIO-North America Study Group. Effect of rimonabant, a cannabinoid-1 receptor blocker, on weight and cardiometabolic risk factors in overweight or obese patients. RIO-North America: a randomized controlled trial. JAMA 2006; 295: 761-75. 
19 Després JP, Golay A, Sjöström L; Rimonabant in Obesity-Lipids Study Group. Effects of rimonabant on metabolic risk factors in overweight patients with dyslipidemia. N Engl] Med 2005; 353: 2121-34.

20 Matthews DR, Hosker JP, Rudenski AS, Naylor BA, Treacher DF, Turner RC. Homeostasis model assessment: insulin resistance and beta-cell function from fasting plasma glucose and insulin concentrations in man. Diabetologia 1985; 28: 412-19.

21 Ware JE, Sherbourne CD. The MOS 36-item short-form health survey (SF-36). Med Care 1992; 30: $473-83$.

22 Kolotkin RL, Crosby RD, Kosloski KD, Williams GR. Development of a brief measure to assess quality of life in obesity. Obes Res 2001; 9:102-11.

23 Kolotkin RL, Crosby RD. Psychometric evaluation of the Impact Of Weight On Quality Of Life-Lite Questionnaire (IWQOL-Lite) in a community sample. Quality of Life Research 2002; 11:157-71.

24 Hill AJ, Rogers PJ, Blundell JE. Techniques for the experimental measurement of human being behaviour and food intake: a practical guide. IntJ Obes Relat Metab Disord 1995; 19: 361-75.

25 Zigmond AS, Snaith RP. The hospital anxiety and depression scale. Acta Psychiatr Scand 1983; 67: $361-70$.

26 Hochberg Y. A sharper Bonferonni procedure for multiple tests of significance. Biometrika 1988; 75: 800-02.

27 Gadbury GL, Coffey CS, Allison DB. Modern statistical methods for handling missing repeated measurements in obesity trial data: beyond LOCF. Obes Rev 2003; 4:175-84.

28 Wood AM, White IR, Hillsdon M, Carpenter J. Comparison of imputation and modelling methods in the analysis of a physical activity trial with missing outcomes. IntJ Epidemiol 2005; 34: 89-99.

29 Buyse M, Molenberghs G. Criteria for the validation of surrogate endpoints in randomized experiments. Biometrics 1998; 54:1014-29.

30 International Diabetes Federation. Global guideline for type 2 diabetes. http://www.idforg/home/index.cfm?node=1457 (accessed Oct $9,2006)$.

31 American Diabetes Association. Clinical practice recommendations 2005. Diabetes Care 2005; 28 (suppl 1): S1-79.

32 Klein S, Burke LE, Bray GA, et al. Clinical implications of obesity with specific focus on cardiovascular disease: a statement for professionals from the American Heart Association Council on Nutrition, Physical Activity, and Metabolism: endorsed by the American College of Cardiology Foundation. Circulation 2004; 110: 2952-67

33 Stratton IM, Adler AI, Neil HA, et al. Association of glycaemia with macrovascular and microvascular complications of type 2 diabetes (UKPDS 35): prospective observational study. BMJ 2000; 321: 405-12.

34 DeFronzo RA, Ratner RE, Han J, Kim DD, Fineman MS, Baron AD. Effects of exenatide (exendin-4) on glycemic control and weight over 30 weeks in metformin-treated patients with type 2 diabetes. Diabetes Care 2005; 28:1092-100.

35 Gaede P, Vedel P, Larsen N, Jensen GV, Parving HH, Pedersen O. Multifactorial intervention and cardiovascular disease in patients with type 2 diabetes. $N$ Engl J Med 2003; 348: 383-93.

36 Stumvoll M, Goldstein BJ, van Haeften TW. Type 2 diabetes: principles of pathogenesis and therapy. Lancet 2005; 365:1333-46.

37 Eckel RH, Grundy SM, Zimmet PZ. The metabolic syndrome. Lancet 2005; 365:1415-28.

38 Danesh J, Wheeler JG, Hirschfield GM, et al. C-reactive protein and other circulating markers of inflammation in the prediction of coronary heart disease. N Engl J Med 2004; 350:1387-97

39 Cota D, Marsicano G, Tschop M, et al. The endogenous cannabinoid system affects energy balance via central orexigenic drive and peripheral lipogenesis. J Clin Invest 2003; 112: 423-31.

40 Chandran M, Phillips SA, Ciaraldi T, Henry RR. Adiponectin: more than just another fat cell hormone? Diabetes Care 2003; 26: 2442-

41 Sattar N, Wannamethee G, Sarwar N, et al. Adiponectin and coronary heart disease: a prospective study and meta-analysis. Circulation 2006; 114: 623-29

42 Williamson DF, Thompson TJ, Thun M, Flanders D, Pamuk E, Byers T. Intentional weight loss and mortality among overweight individuals with diabetes. Diabetes Care 2000; 23:1499-504.

43 Guare JC, Wing RR, Grant A. Comparison of obese NIDDM and nondiabetic women: short- and long-term weight loss. Obes Res $1995 ; 3: 329-35$ 
Published in: Lancet (2006), vol.368, iss.9548, pp.1660-1672

Status: Postprint (Author's version)

44 Anon. Intensive blood-glucose control with sulphonylureas or insulin compared with conventional treatment and risk of complications in patients with type 2 diabetes (UKPDS 33). UK Prospective Diabetes Study (UKPDS) Group. Lancet 1998; 352: 837-53.

45 Diabetes Prevention Program Research Group. Reduction in the incidence of type 2 diabetes with lifestyle intervention or metformin. $N$ Engl J Med 2002; 346: 393-403.

46 Wing RR, Koeske R, Epstein LH, Nowalk MP, Gooding W, Becker D. Long-term effects of modest weight loss in type II diabetic patients. Arch Intern Med 1987; 147:1749-53

47 Nathan DM, Buse JB, Davidson MB, et al. Management of hyperglycaemia in type 2 diabetes: a consensus algorithm for the initiation and adjustment of therapy: a consensus statement from the American Diabetes Association and the European Association for the Study of Diabetes. Diabetes Care 2006; 29:1963-72.

48 Norris SL, Zhang X, Avenell A, et al. Efficacy of pharmacotherapy for weight loss in adults with type 2 diabetes mellitus: a metaanalysis. Arch Intern Med 2004; 164: 395-404.

49 Padwal R, Li S, Lau D. Long-term pharmacotherapy for overweight and obesity: a systematic review and meta-analysis of randomized controlled trials. Int J Obes Relat Metab Disord 2003; 27:1437-46. 